\title{
Are the effects of dietary lipid content in grazing beef cattle independent of the amount of concentrate supplement?
}

\author{
Os efeitos do teor dietético de lipídeo sobre as \\ características nutricionais e de desempenho \\ são independentes da quantidade de suplemento \\ concentrado?
}

\author{
Matheus Leonardi Damasceno ${ }^{1 *}$; Eriton Egidio Lisboa Valente ${ }^{2}$; Mariana Barbizan ${ }^{1}$; \\ Sidnei Antônio Lopes33; Silvana Teixeira Carvalho²
}

\section{Highlights}

Dietary lipid content affects nutrient intake in beef cattle.

There is no information on about dietary lipid content and supplementation level.

Dietary lipid content and supplementation level have independent effects.

\begin{abstract}
This study aimed to evaluate the effects of levels of concentrate supplement and dietary lipids on the nutritional characteristics, metabolic parameters, and performance of Nellore bulls grazing tropical pasture. Twenty-seven Nellore bulls were allotted to $2 \times 2$ completely randomized factorial design with two levels of supplementation and two levels of dietary lipids. The concentrate supplement was fed at $4 \mathrm{~g} \mathrm{~kg}^{-1} \mathrm{BW}$ (low supplementation) and $8 \mathrm{~g} \mathrm{~kg}^{-1} \mathrm{BW}$ (high supplementation), whereas the dietary lipid content was $28 \mathrm{~g}$ of ether extract (EE) g $\mathrm{g}^{-1}$ on a dry matter basis (DM) (low-lipid diet) and $42 \mathrm{~g} \mathrm{EE} \mathrm{kg}^{-1} \mathrm{DM}$ (high-lipid diet). There was no interaction between the level of concentrate supplement and dietary lipid content on all studied variables. High levels of supplementation led to shorter grazing time and reduced forage dry matter intake (DMF). On the other hand, the DM intake increased with increasing levels of concentrate supplement, with no significant effects on DM digestibility. The dietary lipid content did not affect forage and DM intakes. However, the digestibility of DM and neutral detergent fiber (NDF) were lowest in high-lipid diets. Bulls receiving high levels of supplementation had higher average daily gains than low-supplemented animals.

1 Students of the Doctoral Course of the Postgraduate Program in Animal Science, Department of Animal Science, Western Paraná State University, UNIOESTE, Marechal Cândido Rondon, PR, Brazil. E-mail: matheusld31@gmail.com; maribarbizan94@gmail.com

2 Researchers, Department of Animal Science, Western Paraná State University, UNIOESTE, Marechal Cândido Rondon, PR, Brazil. E-mail: eritonvalente@yahoo.com.br; silteixeira@gmail.com

${ }^{3}$ Researchers, Department of Animal Science, National Institute of Science and Technology in Animal Science, INCT, CA, Viçosa, MG, Brasil. E-mail: sidneyufv@hotmail.com

* Author for correspondence
\end{abstract}

Received: June 23, 2020 - Approved: Oct. 26, 2020 
Neither the amount of concentrate supplement nor the dietary lipid content affected the hot carcass yield and carcass weight. Carcass fat deposition was greater in bulls fed high-lipid diets than in animals receiving low-lipid diets. The effects of the level of concentrate supplement and dietary lipid content on the nutritional characteristics and performance of grazing beef cattle are independent. Concentrate supplementation at $8 \mathrm{~g} \mathrm{~kg}^{-1} \mathrm{BW}$ increases cattle performance but decreases forage utilization. Diets containing $42 \mathrm{~g} \mathrm{EE} \mathrm{kg}^{-1} \mathrm{DM}$ reduces the digestibility of dry matter and fiber fractions, but increases backfat thickness.

Key words: Grain. Pasture. Whole soybean. Supplementation.

\section{Resumo}

Este estudo teve como objetivo avaliar o efeito da quantidade de suplemento concentrado e da concentração de lipídios na dieta, sobre as características nutricionais e metabólicas e o desempenho de touros Nelore em pastagem tropical. Vinte e sete touros Nelore foram distribuídos em esquema fatorial $2 \times 2$ com dois níveis de suplemento e dois níveis de lipídios alimentares). A quantidade de suplemento concentrado foi de $4 \mathrm{~g} \mathrm{~kg}^{-1}$ de PC (baixo suplemento) e $8 \mathrm{~g} \mathrm{~kg}^{-1}$ de PC (alto suplemento), enquanto os teores de lipídios dietéticos foram de $28 \mathrm{~g}$ de extrato etéreo (EE) $\mathrm{g}^{-1}$ de matéria seca (MS) (dieta com baixo lipídios) e $42 \mathrm{~g}$ de EE kg-1 de MS (dieta com alto lipídios). Não houve interação entre a quantidade de suplemento concentrado e o teor dietético de lipídios para todas as variáveis analisadas. Os altos níveis de suplemento reduziram o tempo de pastejo e consumo de matéria seca de forragem (MSF). Por outro lado, o consumo MS aumentou com as maiores quantidades de suplemento concentrado, sem qualquer efeito sobre a digestibilidade da MS. O teor de lipídios não afetou o consumo de forragem e MS. No entanto, a digestibilidade da MS e da fibra detergente neutro (FDN) foram mais baixas para as dietas com elevado teor de lipídios. Os touros que receberam níveis elevados de suplementos obtiveram maior ganho médio diário. Nem a quantidade de suplemento concentrado, nem o teor dietético de lipídeo foram influenciaram no rendimento e no peso da carcaça quente. Os touros que receberam alto teor dietético de lipídio, apresentaram maior deposição de gordura na carcaça. Os efeitos do nível de suplemento concentrado e do teor de lipídios da dieta sobre as características nutricionais e desempenho de bovinos de corte em pastejo são independentes. A oferta de $8 \mathrm{~g} \mathrm{~kg}^{-1}$ de PC de suplemento de concentrado aumenta o desempenho dos bovinos, mas diminui a utilização de forragens. O conteúdo lipídico de $42 \mathrm{~g}$ de $\mathrm{EE} \mathrm{kg}^{-1}$ de $\mathrm{MS}$ reduz a digestibilidade da matéria seca e fibras, mas aumenta a deposição de gordura subcutânea.

Palavras-chave: Grãos. Pastagem. Soja. Suplementação.

\section{Introduction}

Beef cattle cannot express their full genetic potential on tropical pastures. Therefore, supplements are an essential strategy for enhancing animal performance and increasing backfat deposition in the carcasses (Poppi, Quigley, Silva, \& McLennan, 2018). However, using grains as a source of starch or lipids may decrease forage utilization due to the negative associative effects between pasture and concentrate supplements (Aldrich, Merchen, \& Drackley, 1995; M. A. Souza et al., 2010).

Cattle performance can be improved if lipid supplementation increases energy intake (Rosa et al., 2013). However, supplementation with excessively high levels of lipids has been associated with reduced dry matter and energy intakes and low body weight gain in cattle 
(Jordan et al., 2006). Although lipids have been extensity studied in feedlot trials, there is not enough data from experiments with grazing cattle. The extrapolation of information from feedlot to grazing production systems can be biased due to differences between diets, primarily because of the fiber content and synchrony of nutrient supply. Both the amount of concentrate supplement and dietary lipid content can affect rumen microorganisms (Carvalho et al., 2011; Kairenius et al., 2018), with adverse effects on ruminal digestion. High-lipid diets are associated with decreased DM intake (Fiorentini et al., 2012) and reduced fiber digestibility in the rumen (Hall, Goetsch, Landis, Forster, \& Brake, 1990). The DM intake is not usually reduced in feedlot cattle fed diets with EE levels up to 5-6\% (Felton \& Kerley, 2004; Messana et al., 2014). Although there are few studies evaluating the dietary lipid content for grazing cattle, low lipid levels (3-4\%) usually do not change the DM and forage intake (Almeida et al., 2018; Brokaw, Hess, \& Rule, 2001).

Total mixed rations are widely used in feedlots due to their high degree of nutrient synchrony in the rumen. However, shortterm changes in nutrient synchrony occur in grazing cattle receiving concentrate supplementation. Although rumen microbiota is inherently adaptable to asynchronous nutrient supply (Reynolds \& Kristensen, 2008), diet modifications may also change the microbial population due to an increased supply of non-fiber carbohydrates (Carvalho et al., 2011). Therefore, short-term changes in the ruminal environment due to the high amount of starch and fat after supplement intake may differ from synchronous diets (feedlot) in terms of nutritional characteristics. Although dietary fat is not significantly detrimental to the digestibility of non-fiber carbohydrates (Jenkins \& Bridges, 2007), there is no information on the interaction between lipid content and concentrate levels in asynchronous diets. However, changes in the rumen microbial population of grazing cattle caused by increased grain inclusion potentially affect cattle's response to dietary lipid levels. Therefore, we hypothesize that there is a relationship between the amount of concentrate supplement and dietary lipid levels on intake, digestibility, and performance of grazing beef cattle.

This study aimed to evaluate the effects of levels of concentrate supplement and dietary lipids on the nutritional characteristics, metabolic parameters, and performance of Nellore bulls grazing tropical pasture.

\section{Material and Methods}

\section{Animals, diet, and experimental design}

This study was approved by the Ethics Committee on Animal Use (CEUA/ Universidade Estadual do Oeste do Paraná - under the process $n^{\circ} 27 / 16$ ), following the ethical principles of animal experimentation established by the Brazilian Council of Animal Experimentation Control (CONCEA).

The study was carried out in the municipality of Entre Rios do Oeste, Paraná,

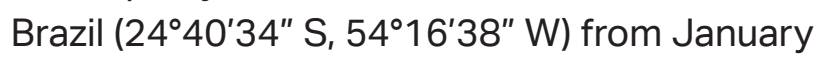
to April 2017. Twenty-seven Nellore bulls averaging 22 months and $439.3 \pm 27.8 \mathrm{~kg}$ of initial body weight (BW) were randomly assigned to four treatments (three treatments with seven replicates each and one treatment with six replicates). The bulls were allowed 10 days of adaptation to diets and facilities, and data were collected for 84 days. 
A $2 \times 2$ completely randomized factorial design with four treatments (two levels of supplementation and two levels of dietary lipids) was used. The concentrate supplement was fed at $4 \mathrm{~g} \mathrm{~kg}^{-1} \mathrm{BW}$ (low supplementation) and $8 \mathrm{~g} \mathrm{~kg}^{-1}$ BW (high supplementation), whereas the dietary lipid content was $28 \mathrm{~g}$ of ether extract (EE) $\mathrm{g}^{-1}$ on a dry matter basis (DM) (low-lipid diet) and $42 \mathrm{~g} \mathrm{EE} \mathrm{kg}^{-1} \mathrm{DM}$ (high-lipid diet) (Table 1). The mineral supplement was offered ad libitum.

Table 1

Ingredients and chemical composition of the diet

\begin{tabular}{|c|c|c|c|c|c|}
\hline & \multirow{2}{*}{ Forage } & \multicolumn{2}{|c|}{ Low supplementation ${ }^{1}$} & \multicolumn{2}{|c|}{ High supplementation $^{1}$} \\
\hline & & Low-lipid & High-lipid & Low-lipid & High-lipid \\
\hline \multicolumn{6}{|l|}{ Ingredient ( $\left.\mathrm{g} \mathrm{kg}^{-1} \mathrm{DM}\right)$} \\
\hline Corn & & 330 & 200 & 685 & 620 \\
\hline Soybean meal & & 350 & 0 & 275 & 100 \\
\hline Raw whole soybeans & & 320 & 800 & 40 & 280 \\
\hline \multicolumn{6}{|c|}{ Chemical composition ( $\left.\mathrm{g} \mathrm{kg}^{-1} \mathrm{DM}\right)$} \\
\hline Organic matter & 913 & 950 & 950 & 970 & 970 \\
\hline Crude protein & 101 & 330 & 330 & 210 & 220 \\
\hline Ether extract & 21 & 80 & 160 & 40 & 80 \\
\hline Non-fiber carbohydrates & 150 & 438 & 416 & 584 & 573 \\
\hline Neutral detergent fiber & 642 & 190 & 200 & 170 & 180 \\
\hline
\end{tabular}

${ }^{1}$ Low supplementation $=4 \mathrm{~g}$ of supplement $\mathrm{kg}^{-1} \mathrm{BW}$; High supplementation $=8 \mathrm{~g}$ of supplement $\mathrm{kg}^{-1} \mathrm{BW}$; Low-lipid diet $=$ $28 \mathrm{~g} \mathrm{EE} \mathrm{kg}^{-1} \mathrm{DM}$; High-lipid diet $=42 \mathrm{~g} \mathrm{EE} \mathrm{kg}^{-1} \mathrm{DM}$.

Each group was kept on 2-ha paddocks planted with Urochloa brizantha cv. Xaraés grass and managed under continuous stocking. The bulls were supplemented daily at 11 a.m. and were rotated among paddocks every seven days to minimize the possible effects of the paddock on experimental treatments (Table 1).

\section{Measurements and sampling}

The forage mass was evaluated every $28 \mathrm{~d}$ by cutting three samples of $0.25 \mathrm{~m}^{2}$ at 1 cm above the ground level in each paddock. The forage accumulation rate was evaluated using three $1-\mathrm{m}^{2}$ exclusion cages randomly placed in each paddock. Forage accumulation was calculated by subtracting the forage mass ( $\mathrm{kg} \mathrm{DM} \mathrm{ha}^{-1}$ ) at the beginning of the evaluation period from the forage mass inside the cages after $28 \mathrm{~d}$. The forage accumulation rate (kg DM $\mathrm{ha}^{-1} \mathrm{~d}^{-1}$ ) was calculated by dividing the forage accumulation by the period of evaluation (28 d). Forage samples were collected using the hand-plucking method at the beginning of the experiment and every $14 \mathrm{~d}$ to estimate the chemical composition of ingested forage. 
The grazing behavior of bulls was evaluated by visual observation during twelve consecutive hours (7 a.m. to 7 p.m.) on days 17 and 18, 52 and 53, 73 and 74. Trained observers were positioned at strategic locations outside the paddocks (at $10 \mathrm{~m}$ of distance) without interfering with the normal behavior of bulls. The time spent grazing was recorded.

From the $33^{\text {rd }}$ and $40^{\text {th }}$ day of the experimental period, a digestibility trial was carried out to evaluate the voluntary intake, nutrient digestibility, and fecal excretion of whole soybeans. The fecal collection was carried out at 4:30 p.m. on day 38, at 11 a.m. on day 39, and at 6 a.m. on day 40. Fecal samples $(200 \mathrm{~g})$ were taken immediately after spontaneous defecation, stored in plastic bags, and frozen $\left(-20^{\circ} \mathrm{C}\right)$ for further analysis. A total of $130 \mathrm{~g}$ of feces from each sampling day (3 d) was collected to evaluate the relationship between soybean intake and excretion. The samples were washed through a 4-mm mesh sieve to estimate the fecal excretion of whole soybeans. The fecal output $(\mathrm{kg})$ was estimated using titanium dioxide $\left(\mathrm{TiO}_{2}\right)$ as an external marker (Myers, Ludden, Nayigihugu, \& Hess, 2004). A total of $15 \mathrm{~g} \mathrm{~d}^{-1}$ of titanium dioxide was wrapped in paper cartridges and introduced (11 a.m.) into the esophagus of each animal by a flexible rubber tube. The fecal output was determined by dividing the amount of titanium dioxide supplied daily $(\mathrm{kg})$ by the marker concentration in the feces $\left(\mathrm{kg} \mathrm{kg}^{-1}\right)$.

The individual supplement intake $(\mathrm{kg}$ $\mathrm{d}^{-1}$ ) was estimated using chromium oxide $\left(\mathrm{Cr}_{2} \mathrm{O}_{3}\right)$ as an external marker (Williams, David, \& lismaa, 1962). A total of $15 \mathrm{~g}_{\text {animal }}{ }^{-1} \mathrm{~d}^{-1}$ was mixed with the concentrate supplement. The individual intake of the supplement was estimated according to the following equation:

$$
\mathrm{SI}=\frac{\mathrm{FO} \times \mathrm{MCF}}{\mathrm{MCS}}
$$

Where: $\mathrm{SI}$ is the supplement intake $\left(\mathrm{kg} \mathrm{d}^{-1}\right), \mathrm{FO}$ is the fecal output $\left(\mathrm{kg} \mathrm{d}^{-1}\right), \mathrm{MCF}$ is the marker concentration in the feces $\left(\mathrm{kg} \mathrm{kg}^{-1}\right)$, and MCS is the marker concentration in the supplement $\left(\mathrm{kg} \mathrm{kg}^{-1}\right)$.

The dry matter intake was calculated by the following equation:

$$
\mathrm{DMI}=\frac{\left[\left(\mathrm{FO}_{\mathrm{x}} \mathrm{iNDF}_{\text {feces }}\right)-\mathrm{iNDF}_{\text {supplement }}\right]}{\mathrm{iNDF}_{\text {forage }}}+\mathrm{SI}
$$

Where DMl is the dry matter intake $\left(\mathrm{kg} \mathrm{d}^{-1}\right)$, FO is the fecal output $\left(\mathrm{kg} \mathrm{d}^{-1}\right)$, iNDF feces is the neutral detergent fiber (iNDF) concentration in the feces $\left(\mathrm{kg} \mathrm{kg}^{-1}\right)$, iNDF ${ }_{\text {supplement }}$ is the iNDF concentration in the supplement (kg), iNDF ${ }_{\text {forage }}$ is the iNDF concentration in the forage $\left(\mathrm{kg} \mathrm{kg}^{-1}\right)$, and $\mathrm{SI}$ is the supplement intake.

Urine, ruminal fluid, and blood samples were collected 4 hours before and 4 hours after supplementation from half of the animals per day (days 42 and 43). Urine samples were collected after spontaneous urination, diluted in $\mathrm{H}_{2} \mathrm{SO}_{4}\left(0.036 \mathrm{~N}\right.$ ) at a ratio of 1: 4 (urine: $\mathrm{H}_{2} \mathrm{SO}_{4}$ ) and frozen at $-20^{\circ} \mathrm{C}$. Subsequently, urine samples were analyzed for concentrations of creatinine, nitrogen, allantoin, and uric acid. Aliquots of $25 \mathrm{~mL}$ of ruminal fluid were sampled via esophageal tubing with the aid of a vacuum pump, and the $\mathrm{pH}$ was immediately measured. A total of $0.5 \mathrm{~mL}$ of $\mathrm{H}_{2} \mathrm{SO}_{4}$ (50\%) was added to the sampled material, and the mixture was frozen at $-20^{\circ} \mathrm{C}$. Subsequently, the rumen ammonia nitrogen concentration was determined. Blood samples were collected by jugular venipuncture into vacuum tubes and centrifuged at $3,000 \mathrm{~g}$ for 15 minutes to obtain the serum, which was frozen at $-20^{\circ} \mathrm{C}$. Then, the urea nitrogen concentration was determined. 
Animal performance was evaluated by weighing the bulls at the beginning and end of the experiment after 14 hours of fasting from solids. The bulls were weighed unfasted ( 8 a.m.) at the beginning of the experiment and every 28 days to adjust the amount of concentrate supplement to be supplied to each group.

\section{Chemical analysis}

Samples of forage, feces, and supplement ingredients were oven-dried at $55^{\circ} \mathrm{C}$ for 72 hours and ground to pass a 1-mm screen, except for indigestible neutral detergent fiber (iNDF) determinations, in which samples were ground to 2-mm. Samples were analyzed for DM (method no. 920.39), crude protein (CP) (method no. 954.01), organic matter (OM) (method no. 942.05), and ether extract (EE) (method no. 920.39) as described by Association of Official Analytical Chemists [AOAC] (1990). Samples were treated with thermostable $\alpha$-amylase without sodium sulfite (Mertens, 2002) to analyze the neutral detergent fiber (NDF) content.

The iNDF content in feed and fecal samples was evaluated using F57 filter bags (Ankom, Macedon, NY, USA) incubated in the rumen for 288 hours (Valente et al., 2011). Fecal samples were analyzed for chromium and titanium dioxide concentrations using atomic absorption and colorimetric methods, respectively. The methodologies used to determine the concentration of external and internal markers have been described above. The total digestible nutrients (TDN) and nonfibrous carbohydrates (NFC) were calculated according to Sniffen, O'Connor, Van Soest, Fox and Russell (1992). The whole soybeans were collected manually, weighed, and analyzed for DM content as previously described (Rennó et al., 2015). The total soybean excretion in feces was calculated as the concentration of grains in feces multiplied by the daily fecal output.

The urinary nitrogen compounds were analyzed by the Kjeldahl method as previously described. Urinary creatinine and uric acid concentrations were analyzed using commercially available test kits (Analisa ${ }^{\circledR}$ Belo Horizonte, MG, BR). Urinary allantoin concentration was analyzed using highperformance liquid chromatography (George et al., 2006). Rumen fluid was analyzed for rumen ammonia nitrogen (RAN) concentration using the colorimetric method (Chaney \& Marbach, 1962) by replacing phenol with sodium salicylate (Felix \& Cardoso, 2004). Urea concentration was analyzed in serum samples using a commercial kit (Gold Analisa, Belo Horizonte, MG, Brazil).

\section{Urine volume and purine derivatives}

The daily urine volume was calculated by the relationship between the daily creatinine excretion and its concentration in spot samples (Silva et al., 2012), using the shrunk body weight estimated according to Valadares et al. (2016):

$$
\mathrm{CE}=0.0345 \times \mathrm{SBW}^{0.9491}
$$

Where: CE is the creatinine excretion $(\mathrm{g} / \mathrm{d})$, and SBW is the shrunk body weight $(\mathrm{kg})$.

The total excretion of purine derivatives was calculated as the sum of allantoin and uric acid excreted in the urine. Absorbed purines were calculated from the excretion of purine derivatives, according to Barbosa et al. (2011):

$$
\mathrm{AP}=\frac{\mathrm{PD}-0.301 \times \mathrm{BW}^{0.75}}{0.80}
$$

Where: AP is the absorbed purines $\left(\mathrm{mmol} \mathrm{d}^{-1}\right)$; $\mathrm{PD}$ is the excretion of the purine derivatives 
$\left(\mathrm{mmol} \mathrm{d}^{-1}\right) ; 0.301$ is the endogenous excretion of purine derivatives in the urine (mmol) per unit metabolic weight (BW0.75), and 0.80 is the recovery of absorbed purine as purine derivatives in urine $\left(\mathrm{mmol} \mathrm{mmol}{ }^{-1}\right)$.

The synthesis of microbial nitrogen compounds in the rumen was calculated as a function of AP according to the equation of (Barbosa et al., 2011):

$$
\text { Nmic }=\frac{70 \times \text { AP }}{0.93 \times R \times 1000}
$$

Where: Nmic is the intestinal flow of microbial nitrogen compounds $\left(\mathrm{g} \mathrm{d}^{-1}\right) ; 70$ is the $\mathrm{N}$ content in purines ( $\mathrm{mg}$ of $\mathrm{N} \mathrm{mol}^{-1}$ ); 0.93 is the digestibility of microbial purines; $\mathrm{R}$ is the purine- $\mathrm{N}$ : total $\mathrm{N}$ in bacteria (0.134).

\section{Carcass quality}

The backfat thickness was evaluated at the beginning and at the end of the experimental period by ultrasound. The fat deposition was calculated by subtracting the final backfat thickness from the initial backfat thickness. Ultrasound images were collected using a Pie Medical-Aquila device (Esaote Europe B.V.) with a linear transducer of $18 \mathrm{~cm}$ and $3.5 \mathrm{MHz}$ frequency. The animals were scanned across the $13^{\text {th }}$ thoracic vertebrae, and the images were analyzed with the SketchUp Pro 2016 software.

On the day after the end of the experimental period, the animals were fasted from solids for 8 hours, weighed to obtain the final BW, and transported to the slaughterhouse. The slaughter procedures followed the Brazilian inspection standards, and the animals were stunned by concussion, bled by cutting the jugular vein, skinned and eviscerated. The carcasses were then identified, washed, and weighed to obtain the hot carcass weight (HCW). The hot carcass yield (\%) was calculated as the ratio between HCW and final BW.

\section{Statistical analysis}

The experiment was conducted as a $2 \times$ 2 completely randomized factorial design with four treatments (two levels of supplementation and two levels of dietary lipids), according to the model:

$$
\mathrm{Yij}=\mu+\mathrm{Si}+\mathrm{Li}+(\mathrm{S} \times \mathrm{L}) i j+e i j
$$

where $Y_{i j}$ is the dependent variable; $\mu=$ the overall mean; $\mathrm{Si}$ is the fixed effect of supplementation level; $\mathrm{Lj}$ is the fixed effect of lipid level; $(\mathrm{S} x \mathrm{~L}) \mathrm{ij}$ is the interaction between the main effects; and eij is the random error associated with $Y i j$, distributed as eijk N (0, $\left.\sigma e^{2}\right)$.

Means were compared by orthogonal contrasts. The initial body weight was used as a covariate in the analyses of final body weight. Data were analyzed using the MIXED procedure of SAS (SAS University Edition) with $\alpha=0.10$ for reducing type II error.

\section{Results and Discussion}

Forage allowance is critical to ruminants and interferes with the effects of supplementation on cattle performance. The minimum recommended forage allowance is dependent on forage species; however, the forage allowance in this study was considerably high (Oliveira et al., 2016), thereby ensuring that the effects of supplementation were not limited by lack of forage. The mean forage mass 
was $6,536 \mathrm{~kg} \mathrm{DM} \mathrm{ha}^{-1}$, while the stocking rate was $1,696 \mathrm{~kg} \mathrm{BW} \mathrm{ha}^{-1}$. The forage allowance was $3.85 \mathrm{~kg} \mathrm{DM} \mathrm{kg} \mathrm{BW}^{-1}$, and the mean forage accumulation rate was $117 \mathrm{~kg} \mathrm{DM} \mathrm{ha}^{-1} \mathrm{~d}^{-1}$.

There was no interaction between the level of concentrate supplement and lipid content on the studied variables (Table 2). Bulls receiving high levels of supplementation spent less time grazing than those receiving low levels of concentrate supplement (Table 3). Grazing activities decreased with increasing supplementintakeas a result of the substitution effect (Mendes et al., 2015). Although the DM intake increased with increasing levels of concentrate supplementation, the forage intake and the time spent grazing decreased in high-supplemented bulls. The reduced time spent grazing may be associated with lower physical activity levels and, consequently, the energy expenditure is reduced (Valente et al., 2019).

\section{Table 2}

Probabilities for fixed effects of level of concentrate supplement, dietary lipid content and their interactions on intake, digestibility, ruminal parameters, and performance of Nellore bulls grazing tropical pastures

\begin{tabular}{|c|c|c|c|}
\hline \multirow{2}{*}{ Variable1 } & \multicolumn{3}{|c|}{$P$-value ${ }^{2}$} \\
\hline & S & L & $S \times L$ \\
\hline \multicolumn{4}{|c|}{ Intake of nutrients } \\
\hline Grazing time & 0.009 & 0.944 & 0.153 \\
\hline Dry matter of forage & $<0.001$ & 0.980 & 0.937 \\
\hline Dry matter of supplement & 0.074 & 0.960 & 0.246 \\
\hline Dry matter & 0.039 & 0.961 & 0.255 \\
\hline Organic matter & 0.240 & 0.835 & 0.687 \\
\hline Crude protein & 0.573 & $<0.001$ & 0.795 \\
\hline Ether extract & 0.125 & 0.962 & 0.171 \\
\hline Neutral detergent fiber & $<0.001$ & 0.172 & 0.445 \\
\hline Non-fiber carbohydrates & 0.031 & 0.232 & 0.327 \\
\hline Digestible organic matter & 0.039 & 0.415 & 0.357 \\
\hline Total digestible nutrients & $<0.001$ & $<0.001$ & 0.714 \\
\hline Intake of whole soybeans & $<0.001$ & 0.005 & 0.759 \\
\hline Fecal excretion of whole soybeans & 0.014 & 0.745 & 0.922 \\
\hline \multicolumn{4}{|c|}{ Digestibility of nutrients } \\
\hline Dry matter & 0.150 & 0.013 & 0.554 \\
\hline Organic matter & 0.124 & 0.002 & 0.734 \\
\hline Crude protein & 0.296 & 0.757 & 0.213 \\
\hline Ether extract & 0.634 & 0.010 & 0.712 \\
\hline Neutral detergent fiber & 0.648 & 0.008 & 0.140 \\
\hline Non-fiber carbohydrates & 0.185 & 0.108 & 0.127 \\
\hline
\end{tabular}


contuation...

\begin{tabular}{|c|c|c|c|}
\hline \multicolumn{4}{|c|}{ Ruminal parameters } \\
\hline $\mathrm{pH}_{\mathrm{m}}$ & 0.016 & 0.005 & 0.458 \\
\hline $\mathrm{pH}_{\mathrm{a}}$ & 0.020 & 0.037 & 0.928 \\
\hline Rumen ammonia nitrogen & 0.001 & 0.174 & 0.325 \\
\hline Urinary nitrogen excretion & 0.002 & 0.091 & 0.716 \\
\hline Serum urea nitrogen & 0.079 & 0.866 & 0.922 \\
\hline Microbial nitrogen & 0.558 & 0.874 & 0.232 \\
\hline \multicolumn{4}{|c|}{ Performance and carcass traits } \\
\hline Average daily gain & 0.065 & 0.706 & 0.957 \\
\hline Body weight gain & 0.065 & 0.706 & 0.957 \\
\hline Final weight & 0.065 & 0.706 & 0.957 \\
\hline Hot carcass weight & 0.162 & 0.507 & 0.469 \\
\hline Carcass yield & 0.880 & 0.259 & 0.714 \\
\hline $\mathrm{BFTi}$ & 0.342 & 0.712 & 0.376 \\
\hline BFTf & 0.126 & 0.029 & 0.505 \\
\hline FD & 0.997 & 0.028 & 0.958 \\
\hline
\end{tabular}

${ }^{1} \mathrm{pHm}=\mathrm{pH}$ in the morning; $\mathrm{pHa}=\mathrm{pH}$ in the afternoon; BFTi $=$ initial backfat thickness; $\mathrm{BFTf}=$ final backfat thickness; FD $=$ fat deposition

${ }^{2} S=$ effect of level of concentrate supplementation; $L=$ effect of dietary lipid content; $S \times L=$ interaction between levels of concentrate supplement and dietary lipid content.

\section{Table 3}

Diurnal grazing time (h), intake $\left(\mathrm{kg} \mathrm{d}^{-1}\right)$, and fecal excretion of whole soybeans (kg d-1) in bulls fed different levels of concentrate supplement and lipids in the diets

\begin{tabular}{|c|c|c|c|c|c|}
\hline \multirow{2}{*}{ Variable $^{1}$} & \multicolumn{2}{|c|}{ Low supplementation ${ }^{2}$} & \multicolumn{2}{|c|}{ High supplementation ${ }^{2}$} & \multirow{2}{*}{ Mean } \\
\hline & Low-lipid & High-lipid & Low-lipid & High-lipid & \\
\hline Grazing time & $4.03 \pm 0.14$ & $4.07 \pm 0.10$ & $3.66 \pm 0.15$ & $3.77 \pm 0.10$ & $3.87 \pm 0.07$ \\
\hline Dry matter of forage & $7.99 \pm 0.47$ & $8.53 \pm 0.28$ & $7.44 \pm 0.32$ & $6.82 \pm 0.48$ & $7.69 \pm 0.22$ \\
\hline Dry matter of supplement & $1.97 \pm 0.27$ & $1.93 \pm 0.20$ & $3.96 \pm 0.33$ & $3.98 \pm 0.32$ & $3.00 \pm 0.23$ \\
\hline Dry matter & $9.96 \pm 0.60$ & $10.46 \pm 0.35$ & $11.40 \pm 0.50$ & $10.80 \pm 0.40$ & $10.69 \pm 0.25$ \\
\hline Organic matter & $9.17 \pm 0.61$ & $9.63 \pm 0.30$ & $10.64 \pm 0.52$ & $10.09 \pm 0.35$ & $9.91 \pm 0.23$ \\
\hline Crude protein & $1.45 \pm 0.12$ & $1.49 \pm 0.06$ & $1.58 \pm 0.08$ & $1.56 \pm 0.05$ & $1.53 \pm 0.04$ \\
\hline Ether extract & $0.28 \pm 0.02$ & $0.44 \pm 0.02$ & $0.27 \pm 0.01$ & $0.42 \pm 0.02$ & $0.36 \pm 0.02$ \\
\hline Neutral detergent fiber & $5.50 \pm 0.33$ & $5.86 \pm 0.18$ & $5.45 \pm 0.24$ & $5.09 \pm 0.27$ & $5.48 \pm 0.13$ \\
\hline Non-fiber carbohydrates & $1.93 \pm 0.14$ & $1.82 \pm 0.05$ & $3.33 \pm 0.21$ & $3.00 \pm 0.13$ & $2.55 \pm 0.14$ \\
\hline Digestible organic matter & $6.36 \pm 0.47$ & $6.25 \pm 0.23$ & $7.56 \pm 0.43$ & $6.73 \pm 0.30$ & $13.03 \pm 0.20$ \\
\hline Total digestible nutrients & $6.56 \pm 0.45$ & $6.60 \pm 0.30$ & $7.74 \pm 0.49$ & $7.06 \pm 0.25$ & $6.99 \pm 0.20$ \\
\hline Intake of whole soybeans & $0.50 \pm 0.04$ & $1.54 \pm 0.10$ & $0.15 \pm 0.01$ & $1.11 \pm 0.09$ & $0.87 \pm 0.10$ \\
\hline Fecal excretion of whole soybeans & $0.02 \pm 0.18$ & $0.03 \pm 0.10$ & $0.01 \pm 0.01$ & $0.01 \pm 0.06$ & $0.02 \pm 0.03$ \\
\hline
\end{tabular}

${ }^{1}$ Values expressed as mean \pm standard error

${ }^{2}$ Low supplementation $=4 \mathrm{~g}$ of supplement $\mathrm{kg}^{-1} \mathrm{BW}$; High supplementation $=8 \mathrm{~g}$ of supplement $\mathrm{kg}^{-1} \mathrm{BW}$; Low-lipid diet = $28 \mathrm{~g} \mathrm{EE} \mathrm{kg}^{-1} \mathrm{DM}$; High-lipid diet $=42 \mathrm{~g} \mathrm{EE} \mathrm{kg}^{-1} \mathrm{DM}$. 
High levels of supplementation $\left(8 \mathrm{~g} \mathrm{~kg}^{-1}\right.$ BW) decreased forage intake, but increased NFC intake (Table 3). Decreases in forage intake with starch supplementation are frequently observed in grazing beef cattle (Valente et al., 2014) and are associated with changes in the rumen microbial ecosystem, which impairs the rumen dynamics of NDF (Souza et al., 2010). However, the highest NFC intake did not alter the dietary NDF intake. Other authors (Figueiras et al., 2010; Lazzarini et al., 2016) reported that this effect is commonly observed and that NFC intake has a lesser adverse effect on NDF intake in cattle grazing medium-quality forage than in animals on low-quality forage. Thus, the lack of effect of supplementation on NDF intake in our study may indicate that physical regulation also played an important role in feed intake (Mertens, 2002).

On the one hand, the $\mathrm{CP}$ intake was similar between bulls fed low and high levels of concentrate supplement. On the other hand, the DM, OM, NFC, DOM (digestible organic matter), and TDN intakes increased with increasing levels of concentrate supplement. The dietary lipid content did not affect the intakes of forage, DM, OM, CP, NDF, NFC, DOM and TDN. In forage-concentrate diets, there are complex interactions between dietary components that may result in different associative effects. The decrease in forage intake was not proportional to the increase in supplement intake. Therefore, although forage intake decreased with increasing supplementation, the increase in the amount of supplement improved the total DM and energy intake (TDN).

The lack of interaction between supplementation level and dietary lipid content on feed intake indicates that the effect of lipids on rumen metabolism is not necessarily dependent on the predominance of amylolytic or fibrolytic microbial populations. The adverse effects of lipid supplementation on rumen metabolism are mainly related to impaired fiber utilization because dietary lipids are less harmful to NFC digestibility than to fiber digestibility (Jenkins, 1993).

The fecal excretion of whole soybeans was higher in bulls receiving low levels of concentrate supplement (Table 3 ) because this group consumed more soybeans to adjust the dietary lipid content. However, fecal soybean excretion was low (lower than $5 \%$ of grain intake) despite this difference between treatments. Although the increase of lipid content also increased the excretion of whole soybeans in feces, the intakes of total DM, forage, NDF, and TDN were not affected by the dietary lipid content. Most of the dietary fat escape from the rumen to the lower gastrointestinal tract (Jenkin \& Bridges, 2007). However, the natural protection of the whole soybean grain can hinder the access of enzymes to lipids. Although there was an increase in the fecal excretion of soybean grains with increasing soybean inclusion, the amount excreted was not significant compared to the intake (6 to $44 \mathrm{~g} \mathrm{~kg}^{-1}$ grain). Low fecal excretion of whole soybeans (50 g kg-1 grain) was also reported in feedlots even at high inclusion levels (250 $\mathrm{g} \mathrm{kg}^{-1}$ DM) (Rennó et al., 2015), which indicates that cattle have high efficiency in degrading whole soybeans.

High levels of concentrate supplementation did not change the digestibility of DM, CP, EE, NDF, and NFC, but improved OM digestibility. However, high lipid contents reduced the digestibility of DM, NDF, and OM, but increased EE digestibility (Table 4).

The inclusion of concentrate in diets for cattle grazing tropical pastures is usually associated with competition between 
microorganisms for substrates and decreased fiber digestibility (Lazzarini et al., 2016). Nevertheless, the amount of concentrate supplement did not decrease fiber digestibility (Table 4). The adverse effects of starch on NDF digestibility is dependent on CP intake (Souza et al., 2010). In all treatments, the dietary CP content was similar and sufficient to meet both the microbial and animal requirements (Valadares et al., 2016). Therefore, microbial competition for substrate utilization and their deleterious effects on fiber degradation were probably reduced by an adequate protein supply.

\section{Table 4}

Diurnal grazing time (h), intake ( $\left.\mathrm{kg} \mathrm{d}^{-1}\right)$, and fecal excretion of whole soybeans (kg d-1) in bulls fed different levels of concentrate supplement and lipids in the diets

\begin{tabular}{|c|c|c|c|c|c|}
\hline \multirow{2}{*}{ Variable $^{1}$} & \multicolumn{2}{|c|}{ Low supplementation ${ }^{2}$} & \multicolumn{2}{|c|}{ High supplementation ${ }^{2}$} & \multirow{2}{*}{ Mean } \\
\hline & Low-lipid & High-lipid & Low-lipid & High-lipid & \\
\hline Dry matter & $64.67 \pm 1.41$ & $62.28 \pm 0.74$ & $67.40 \pm 0.43$ & $63.31 \pm 1.71$ & $61.15 \pm 0.63$ \\
\hline Organic matter & $69.05 \pm 0.59$ & $65.72 \pm 1.15$ & $71.57 \pm 0.74$ & $67.06 \pm 1.48$ & $68.38 \pm 0.63$ \\
\hline Crude protein & $72.62 \pm 0.64$ & $73.56 \pm 0.74$ & $73.90 \pm 1.01$ & $73.35 \pm 1.08$ & $73.35 \pm 0.43$ \\
\hline Ether extract & $50.00 \pm 9.20$ & $61.96 \pm 1.81$ & $54.88 \pm 3.23$ & $61.44 \pm 2.87$ & $57.07 \pm 2.38$ \\
\hline Neutral detergent fiber & $62.43 \pm 0.82$ & $59.99 \pm 1.57$ & $66.13 \pm 0.85$ & $57.98 \pm 2.69$ & $61.63 \pm 0.98$ \\
\hline Non-fiber carbohydrates & $82.30 \pm 4.61$ & $78.68 \pm 1.71$ & $82.33 \pm 1.81$ & $79.16 \pm 1.49$ & $80.61 \pm 1.38$ \\
\hline
\end{tabular}

${ }^{1}$ Values expressed as mean \pm standard error

${ }^{2}$ Low supplementation $=4 \mathrm{~g}$ of supplement $\mathrm{kg}^{-1} \mathrm{BW}$; High supplementation $=8 \mathrm{~g}$ of supplement $\mathrm{kg}^{-1} \mathrm{BW}$; Low-lipid diet $=$ $28 \mathrm{~g} \mathrm{EE} \mathrm{kg}^{-1} \mathrm{DM}$; High-lipid diet $=42 \mathrm{~g} \mathrm{EE} \mathrm{kg}^{-1} \mathrm{DM}$.

Although the maximum dietary EE content was $42 \mathrm{~g} \mathrm{~kg}^{-1} \mathrm{DM}$, which is not enough to affect the nutritional characteristics in feedlot studies (Messana et al., 2014), the NDF and OM digestibilities were lower in high-lipid than in low-lipid diets. The high proportion of forage in diets helped to reduce the digestibility of OM and NDF with increasing lipid levels because forage-based diets are more susceptible to disrupt rumen fermentation with lipid inclusion (Jenkins, 1993). Other studies have also observed this same effect (Carvalho et al., 2016, 2017). The EE digestibility increased with increasing lipid levels due to the lower relative contribution of metabolic fecal metabolic fraction to EE excretion.
Bullsreceivinghighlevelsof concentrate supplement had lower concentrations of rumen ammonia nitrogen (RAN), serum urea nitrogen (SUN) and urinary nitrogen excretion (UNE) than low-supplemented animals. The dietary lipid content did not affect the RAN, SUN, and UNE concentrations (Table 5). An optimum protein: starch ratio in supplements improves nitrogen assimilation and minimizes $\mathrm{N}$ excretion (Souza et al., 2010). Although CP intake was not affected by the concentrate supplement or lipid content, the NFC intake increased in bulls receiving a high supplementation level compared with lowsupplemented animals. Thus, the increase of NFC intake increased the nitrogen assimilation 
by rumen microorganisms and, consequently, reduced urea levels in the blood and the urinary nitrogen excretion.

Neither the amount of concentrate supplement nor the dietary lipid content affected the $\mathrm{N}_{\text {mic }}$ production and efficiency of microbial protein synthesis (Table 4). Although dietary lipids cannot supply energy to rumen microorganisms (Jenkins, 1993) and have potentially adverse effects on microbial growth, the dietary lipid content was not sufficiently high to modify the Nmic production and efficiency of microbial protein synthesis. Bulls receiving high levels of concentrate supplement had lower ruminal $\mathrm{pH}$ after supplementation than low-supplemented animals. Moreover, bulls fed high-lipid diets had lower ruminal $\mathrm{pH}$ before supplementation than animals fed low-lipid diets. Rumen $\mathrm{pH}$ was lower after supplementation due to the increase of NFC fermentation. The higher rumen $\mathrm{pH}$ in bulls fed high-lipid diets may be attributed to an indirect effect of lipid inclusion. The increase of lipid levels can modify the ruminal environment, thereby resulting in greater variability in $\mathrm{pH}$ (Messana et al., 2013; Santana et al., 2017). However, this variation was not observed in our study. According to Demeyer and Van Nevel (1995), protected lipid sources such as soybean grains are less harmful to ruminal microorganisms. Therefore, no reduction in rumen $\mathrm{pH}$ was observed.

\section{Table 5}

\section{Ruminal parameters in bulls fed different levels of concentrate supplement and lipids in the diet}

\begin{tabular}{|c|c|c|c|c|c|}
\hline \multirow{2}{*}{ Variable $^{1}$} & \multicolumn{2}{|c|}{ Low supplementation ${ }^{2}$} & \multicolumn{2}{|c|}{ High supplementation ${ }^{2}$} & \multirow{2}{*}{ Mean } \\
\hline & Low-lipid & High-lipid & Low-lipid & High-lipid & \\
\hline $\mathrm{pHm}$ & $7.12 \pm 0.40$ & $6.89 \pm 0.08$ & $7.48 \pm 0.11$ & $7.08 \pm 0.09$ & $7.14 \pm 0.05$ \\
\hline $\mathrm{pHa}$ & $6.96 \pm 0.16$ & $7.21 \pm 0.13$ & $6.69 \pm 0.03$ & $6.92 \pm 0.08$ & $6.94 \pm 0.05$ \\
\hline RAN (mg dL-1) & $12.46 \pm 0.56$ & $10.80 \pm 0.89$ & $8.27 \pm 0.45$ & $8.02 \pm 1.01$ & $9.88 \pm 0.49$ \\
\hline UNE (mg dL-1) & $102.56 \pm 10.73$ & $112.56 \pm 5.89$ & $75.14 \pm 4.93$ & $90.62 \pm 6.79$ & $95.22 \pm 4.21$ \\
\hline SUN (mg dL-1) & $16.72 \pm 0.73$ & $16.57 \pm 0.78$ & $14.68 \pm 1.02$ & $14.94 \pm 1.19$ & $15.72 \pm 0.50$ \\
\hline Microbial nitrogen $\left(\mathrm{g} \mathrm{d}^{-1}\right)$ & $117.67 \pm 5.45$ & $125.43 \pm 4.55$ & $123.01 \pm 10.57$ & $110.82 \pm 6.70$ & $119.23 \pm 2.82$ \\
\hline
\end{tabular}

${ }^{1}$ Values expressed as mean \pm standard error; $\mathrm{pHm}=\mathrm{pH}$ in the morning; $\mathrm{pHa}=\mathrm{pH}$ in the afternoon; $\mathrm{RAN}=$ rumen ammonia nitrogen; UNE = urinary nitrogen excretion; SUN: serum urea nitrogen

${ }^{2}$ Low supplementation $=4 \mathrm{~g}$ of supplement $\mathrm{kg}^{-1} \mathrm{BW}$; High supplementation $=8 \mathrm{~g}$ of supplement kg-1 BW; Low-lipid diet $=$ $28 \mathrm{~g} \mathrm{EE} \mathrm{kg}{ }^{-1} \mathrm{DM}$; High-lipid diet $=42 \mathrm{~g} \mathrm{EE} \mathrm{kg}^{-1} \mathrm{DM}$.

Bulls receiving high levels of supplement had higher average daily gain (ADG), BW gain, and final BW (Table 6) than low-supplemented animals. This improved performance is explained by the supplementation per se, which increased energy intake. Many authors have reported similar results in beef cattle on tropical forages receiving protein supplementation (Valente, Paulino, Detmann, Valadares, \& Lopes, 2013; Detmann, Valente, Batista, \& Huhtanen, 2014; Poppi et al., 2018). The lack of effect of lipid content on animal performance was due to the low dietary lipid content. Although the whole 
soybean was added to supplements at high levels, the proportion of forage in the total diet was larger. Therefore, none of the treatments reached considerably high levels of total lipids due to the low lipid content of the forage. On the one hand, bulls fed high-lipid diets (80 to $100 \mathrm{~g}$ of EE $\mathrm{kg}^{-1} \mathrm{DM}$ ) have lower DM intake and performance (Felton \& Kerley, 2004; Jordan et al., 2006). On the other hand, some feedlot studies have shown that cattle performance is not affected by moderate lipid levels (40 to 60 $\mathrm{g}$ of $\mathrm{EE}^{-1} \mathrm{~kg}$ ), even though some authors report a decrease in DM intake (Bassi et al., 2012; Messana et al., 2014).
Neither the amount of concentrate supplement nor the dietary lipid content was high enough to influence the HCW and carcass yield (\%) (Table 6). However, bulls fed high lipid-diets had greater backfat deposition. The improved performance of bulls receiving high levels of concentrate supplement was not enough to influence the final weight and carcass yield. Many studies (Pompei et al., 2018; Menezes et al., 2019) observed this same effect, and the main explanation involves the use of contemporary animals of the same breed and diets with similar energy content.

\section{Table 6}

\section{Performance of bulls fed different levels of concentrate supplement and lipids in the diet}

\begin{tabular}{|c|c|c|c|c|c|}
\hline \multirow{2}{*}{ Variable $^{1}$} & \multicolumn{2}{|c|}{ Low supplementation ${ }^{2}$} & \multicolumn{2}{|c|}{ High supplementation $^{2}$} & \multirow{2}{*}{ Mean } \\
\hline & Low-lipid & High-lipid & Low-lipid & High-lipid & \\
\hline Average daily gain $\left(\mathrm{kg} \mathrm{d}^{-1}\right)$ & $0.95 \pm 0.06$ & $0.97 \pm 0.03$ & $1.05 \pm 0.05$ & $1.08 \pm 0.05$ & $1.01 \pm 0.02$ \\
\hline Body weight gain $(\mathrm{kg})$ & $79.8 \pm 5.8$ & $81.7 \pm 2.9$ & $88.6 \pm 4.9$ & $90.7 \pm 4.8$ & $85.2 \pm 2.3$ \\
\hline Final weight (kg) & $517 \pm 11$ & $523 \pm 17$ & $527 \pm 11$ & $531 \pm 13$ & $525 \pm 6$ \\
\hline Hot carcass weight (kg) & $282.1 \pm 7.2$ & $284.3 \pm 10.4$ & $285.7 \pm 6.9$ & $291.9 \pm 8.6$ & $286.0 \pm 4.1$ \\
\hline Hot carcass yield (\%) & $52.71 \pm 0.45$ & $53.11 \pm 0.22$ & $52.47 \pm 0.63$ & $53.21 \pm 0.48$ & $52.87 \pm 0.23$ \\
\hline $\mathrm{BFTi}(\mathrm{mm})$ & $2.80 \pm 0.10$ & $3.15 \pm 0.28$ & $3.31 \pm 0.17$ & $3.18 \pm 0.33$ & $3.11 \pm 0.43$ \\
\hline BFTf (mm) & $3.65 \pm 0.40$ & $4.64 \pm 0.31$ & $4.34 \pm 0.16$ & $4.86 \pm 0.32$ & $4.37 \pm 0.43$ \\
\hline $\mathrm{FD}(\mathrm{mm})$ & $0.85 \pm 0.49$ & $1.60 \pm 0.15$ & $0.86 \pm 0.30$ & $1.60 \pm 0.20$ & $1.22 \pm 0.37$ \\
\hline
\end{tabular}

${ }^{1}$ Values expressed as mean \pm standard error; BFTi = initial backfat thickness; BFTf = final backfat thickness; FD = fat deposition

${ }^{2}$ Low supplementation $=4 \mathrm{~g}$ of supplement $\mathrm{kg}^{-1} \mathrm{BW}$; High supplementation $=8 \mathrm{~g}$ of supplement kg-1 BW; Low-lipid diet $=$ $28 \mathrm{~g} \mathrm{EE} \mathrm{kg}{ }^{-1} \mathrm{DM}$; High-lipid diet $=42 \mathrm{~g} \mathrm{EE} \mathrm{kg}^{-1} \mathrm{DM}$.

All treatments stimulated backfat deposition in the carcasses. However, the backfat deposition was greater in bulls fed high-lipid diets than in animals receiving lowlipid diets. Lipid sources with some degree of ruminal protection can stimulate the passage of unsaturated fatty acids through the rumen, thereby increasing intestinal absorption (Doreau \& Ferlay, 1994; Lima et al., 2017). Consequently, the metabolic efficiency in adipose tissue anabolism reactions increases (Souza, Medeiros, Morais, Oshiro \& Torres, 2009), which results in greater fat deposition. 


\section{Conclusions}

The effects of the level of concentrate supplement and dietary lipid content on the nutritional characteristics and performance of grazing beef cattle are independent. Concentrate supplementation at $8 \mathrm{~g} \mathrm{~kg}^{-1} \mathrm{BW}$ increases cattle performance but decreases forage utilization. Although diets containing 42 $\mathrm{g}$ EE $\mathrm{kg}^{-1} \mathrm{DM}$ reduced the digestibility of dry matter and fiber fractions, backfat deposition increased without affecting feed intake and animal performance. Supplementation of lipids above $42 \mathrm{~g} \mathrm{~kg}^{-1} \mathrm{DM}$ should be carried out with prudence, regardless of the amount of concentrate supplement to grazing cattle.

\section{Acknowledgments}

This study was financed in part by the Coordenação de Aperfeiçoamento de Pessoal de Nível Superior - Brasil (CAPES) Finance Code 001 and the Conselho Nacional de Pesquisa e Desenvolvimento Científico e Tecnológico (CNPq).

\section{References}

Aldrich, C. G., Merchen, N. R., \& Drackley, J. K. (1995). The effect of roasting temperature applied to whole soybeans on site of digestion by steers: I. Organic matter, energy, fiber, and fatty acid digestion. Journal of Animal Science, 73(7), 21202130. doi: $10.2527 / 1995.7372120 x$

Almeida, D. M., Marcondes, M. I., Rennó, L. N., Martins, L. S., Villadiego, F. A. C., \& Paulino, M. F. (2018). Soybean grain is a suitable replacement with soybean meal in multiple supplements for Nellore heifers grazing tropical pastures. Tropical Animal Health and Production, 50(8), 1843-1849. doi: 10. 10 07/s11250-018-1630-7

Association of Official Analytical Chemists (1990). Official methods of analysis (5nd ed.). Washington: AOAC.

Barbosa, A. M., Valadares, R. F. D., Valadares, S. C., Fo., Pina, D. S., Detmann, E., \& Leão, M. I. (2011). Endogenous fraction and urinary recovery of purine derivatives obtained by different methods in Nellore cattle1. Journal of Animal Science, 89(2), 510-519. doi: 10.2527/jas.2009-2366

Bassi, M. S., Ladeira, M. M., Chizzotti, M. L., Chizzotti, F. H. M., Oliveira, D. M., Machado, O. R., Neto,... Nogueira, Á. A., Neto. (2012). Grãos de oleaginosas na alimentação de novilhos zebuínos: consumo, digestibilidade e desempenho. Revista Brasileira de Zootecnia, 41(2), 353-359. doi: 10.1590/S1516-35 982012000200018

Brokaw, L., Hess, B. W., \& Rule, D. C. (2001). Supplemental soybean oil or corn for beef heifers grazing summer pasture: effects on forage intake, ruminal fermentation, and site and extent of digestion. Journal of Animal Science, 79(10), 2704-2712. doi: $10.2527 / 2001.79102704 x$

Carvalho, I. P. C. de, Detmann, E., Mantovani, H. C., Paulino, M. F., Valadares, S. C., Fo., Costa, V. A. C., \& Gomes, D. I. (2011). Growth and antimicrobial activity of lactic acid bacteria from rumen fluid according to energy or nitrogen source. Revista Brasileira de Zootecnia, 40(6), 1260-1265. doi: 10. 1590/S1516-35982011000600014

Carvalho, I. P. C. de, Fiorentini, G., Berndt, A., Castagnino, P. S., Messana, J. D., Frighetto, R.T.S.,... Berchielli, T. T. (2016). Performance 
and methane emissions of Nellore steers grazing tropical pasture supplemented with lipid sources. Revista Brasileira de Zootecnia, 45(12), 760-767. doi: 10.1590/ S1806-92902016001200005

Carvalho, I. P. C. de, Fiorentini, G., Castagnino, P. S., Jesus, R. B., Messana, J. D., GranjaSalcedo, Y. T.,... Berchielli, T. T. (2017). Supplementation with lipid sources alters the ruminal fermentation and duodenal flow of fatty acids in grazing Nellore steers. Animal Feed Science and Technology, 227(16), 142-153. doi: 10.1016/j. anifeedsci.2017.02.017

Chaney, A. L., \& Marbach, E. P. (1962). Modified reagents for determination of urea and ammonia. Clinical Chemistry, 8(2), 130132. doi: 10.1021/AC60252A045

Demeyer, D. I., \& Van Nevel, C. J. (1995). Transformations and effects of lipids in the rumen: three decades of research at Gent University. Archiv Für Tierernährung, 48(12), 119-134. doi: 10.1080/17450399509 381834

Detmann, E., Valente, É. E., Batista, E. D., \& Huhtanen, P. (2014). An evaluation of the performance and efficiency of nitrogen utilization in cattle fed tropical grass pastures with supplementation. Livestock Science, 162(1), 141-153. doi: 10.1016/j. livsci.2014.01.029

Doreau, M., \& Ferlay, A. (1994). Digestion and utilisation of fatty acids by ruminants. Animal Feed Science and Technology, 45(3-4), 379-396. doi: 10.1016/0377-84 01(94)90039-6

Felix, E. P., \& Cardoso, A. A. (2004). Amônia (NH3) atmosférica: fontes, transformação, sorvedouros e métodos de análise. Quimica Nova, 27(1), 123-130. doi: 10.1590/S0100-40422004000100022

Felton,E.E.D.,\&Kerley,M.S. (2004).Performance and carcass quality of steers fed whole raw soybeans at increasing inclusion levels. Journal of Animal Science, 82(3), 725-732. doi: 10.2527/2004.823725x

Figueiras, J. F., Detmann, E., Paulino, M. F., Valente, T. N. P., Valadares, S. D. C., Fo., \& Lazzarini, I. (2010). Consumo e digestibilidade em bovinos em pastejo durante o período seco recebendo suplementação com compostos nitrogenados. Revista Brasileira de Zootecnia, 39(6), 1303-1312. doi: 10.1590/ S1516-3598 2011000800024

Fiorentini, G., Santana, M. C. A., Sampaio, A. A. M., Reis, R. A., Ribeiro, A. F., \& Berchielli, T. T. (2012). Intake and performance of confined crossbred heifers fed different lipid sources. Revista Brasileira de Zootecnia, 41(6), 1490-1498. doi: 10.1590/ S1516-35982012000600025

George, S. K., Dipu, M. T., Mehra, U. R., Singh, P., Verma, A. K., \& Ramgaokar, J. S. (2006). Improved HPLC method for the simultaneous determination of allantoin, uric acid and creatinine in cattle urine. Journal of Chromatography B, 832(1), 134137. doi: 10.1016/j.jchromb.2005.10.051

Hall, K. L., Goetsch, A. L., Landis, K. M., Forster, L. A., \& Brake, A. C. (1990). Effects of a fat and ground maize supplement on feed intake and digestion by cattle consuming bermudagrass hay (Cynodon dactylon). Animal Feed Science and Technology, 30(3-4), 275-288. doi: 10.1016/0377-84 01(90)90018-4 
Jenkins, T. (1993). Symposium: advances in ruminant lipid metabolism lipid metabolism in the rumen. Journal of Dairy Science, 76(12), 3851-3863. doi: 10.3168/ jds.S0022-0302(93)77727-9

Jenkins, T. C., \& Bridges, W. C. (2007). Protection of fatty acids against ruminal biohydrogenation in cattle. European Journal of Lipid Science and Technology, 109(8), 778-789. doi: 10.1002/ejlt.20070 0022

Jordan, E., Kenny, D., Hawkins, M., Malone, R., Lovett, D. K., \& O'Mara, F. P. (2006). Effect of refined soy oil or whole soybeans on intake, methane output, and performance of young bulls. Journal of Animal Science, 84(9), 2418-2425. doi: 10.2527/jas.2005354

Kairenius, P., Leskinen, $H_{\text {., }}$ Toivonen, $V_{\text {., }}$ Muetzel, S., Ahvenjärvi, S., Vanhatalo, A.,... Shingfield, K. J. (2018). Effect of dietary fish oil supplements alone or in combination with sunflower and linseed oil on ruminal lipid metabolism and bacterial populations in lactating cows. Journal of Dairy Science, 101(4), 3021-3035. doi: 10.3168/jds.2017-13776

Lazzarini, Í., Detmann, E., Valadares, S. C., Fo., Paulino, M. F., Batista, E. D., Rufino, L. M. A.,... Franco, M. O. (2016). Nutritional performance of cattle grazing during rainy season with nitrogen and starch supplementation. Asian-Australasian Journal of Animal Sciences, 29(8), 11201128. doi: 10.5713 /ajas. 15.0514

Lima, E. D. S., Valente, T. N. P., Roca, R. D. O., Cezario, A. S., Santos, W. B. R., Deminicis, B. B., \& Ribeiro, J. C. (2017). Effect of whole cottonseed or protected fat dietary additives on carcass characteristics and meat quality of beef cattle: a review. Journal of Agricultural Science, 9(5), 175. doi: 10.5539/jas.v9n5 p175

Mendes, F. B. L., Silva, R. R., Carvalho, G. G. P., Silva, F. F. da, Lins, T. O. J. D. A., Silva, A. L. N.,... Guimarães, J. O. (2015). Ingestive behavior of grazing steers fed increasing levels of concentrate supplementation with different crude protein contents. Tropical Animal Health and Production, 47(2), 423-428. doi: 10.1007/s11250-014 $-0741-z$

Menezes, B. B., Fernandes, H. J., Morais, M. G., Rosa, E. P., Souza, A. R. D. L., Feijó, G. L. D., \& Franco, G. L. (2019). Carcass traits and meat quality of steers on pasture submitted to different dietary supplementation. Semina: Ciencias Agrarias, 40(6), 2693-2704. doi: 10.5433/1679-0359.2019v40n6p2 693

Mertens, D. R. (2002). Gravimetric determination of amylase-treated neutral detergent fiber in feeds with refluxing in beakers or crucibles: collaborative study. Journal of AOAC International, 85(6), 1217-1240.

Messana, J. D., Berchielli, T. T., Arcuri, P. B., Reis, R. A., Canesin, R. C., Ribeiro, A. F.,... Fernandes, J. J. R. (2013). Rumen fermentation and rumen microbes in Nellore steers receiving diets with different lipid contents. Revista Brasileira de Zootecnia, 42(3), 204-212. doi: 10.1590/ S1516-35982013000300008

Messana, J. D., Canesin, R. C., Fiorentini, G., Reis, R. A., Arcuri, P. B., \& Berchielli, T. T. (2014). Intake, performance and estimated methane production of Nellore steers fed soybean grain. Revista Brasileira de Zootecnia, 43(12), 662-669. doi: 10.1590/ S1516-35982014001200006 
Myers, W.D., Ludden, P.A., Nayigihugu, V., \&Hess, B. W. (2004). Technical note: a procedure for the preparation and quantitative analysis of samples for titanium dioxide. Journal of Animal Science, 82(1), 179-183. doi: $10.2527 / 2004.821179 x$

Oliveira, A. P., Casagrande, D. R., Bertipaglia, L. M. A., Barbero, R. P., Berchielli, T. T., Ruggieri, A. C., \& Reis, R. A. (2016). Supplementation for beef cattle on Marandu grass pastures with different herbage allowances. Animal Production Science, 56(1), 123-129. doi: 10.1071/AN14636

Pompei, J. P., Guerra, G. L., Pereira, E. S., Silva, L. D. D. F., Pimentel, P. G., Ribeiro, E. L. A.,... Mizubuti, I. Y. (2018). Performance and carcass traits of Nellore cattle fattening on pasture receiving different zinc contents in the mineral supplementation. Semina: Ciencias Agrarias, 39(3), 1351-1363. doi: 10.54 33/1679-0359.2018v39n3p1351

Poppi, D. P., Quigley, S. P., Silva, T. A. C. C., \& McLennan, S. R. (2018). Challenges of beef cattle production from tropical pastures. Revista Brasileira de Zootecnia, 47(4), 1-9. doi: 10.1590/rbz472016 0419

Rennó, F. P., Cônsolo, N. R. B., Barletta, R. V., Ventureli, B., Gardinal, R., Takiya, C. S.,... Pereira, A. S. C. (2015). Grão de soja cru e inteiro na alimentação de bovinos: excreção de grão de soja nas fezes. Archivos de Zootecnia, 64(248), 331-338.

Reynolds, C. K., \& Kristensen, N. B. (2008). Nitrogen recycling through the gut and the nitrogen economy of ruminants: an asynchronous symbiosis1. Journal of Animal Science, 86(Suppl. 14), E293-E305. doi: 10.2527/jas.2007-0475
Rosa, B. L., Sampaio, A. A. M., Henrique, W., Oliveira, E. A., Pivaro, T. M., Andrade, A. T., \& Fernandes, A. R. M. (2013). Performance and carcass characteristics of Nellore young bulls fed different sources of oils, protected or not from rumen degradation. Revista Brasileira de Zootecnia, 42(2), 109116. doi: 10. 1590/S1516-359820130002 00005

Santana, M. C. A., Fiorentini, G., Messana, J. D., Dian, P. H. M., Canesin, R. C., Reis, R. A., \& Berchielli, T. T. (2017). Different forms and frequencies of soybean oil supplementation do not alter rumen fermentation in grazing heifers. Animal Production Science, 57(3), 530-538. doi: 10.1071/AN14608

Silva, L. F. C., Valadares, S. C., Fo., Chizzotti, M. L., Rotta, P. P., Prados, L. F., Valadares, R. F. D.,... Silva Braga, J. M. (2012). Creatinine excretion and relationship with body weight of Nellore cattle. Revista Brasileira deZootecnia, 41(3), 807-810. doi:10.1590/ S1516-35982012000300046

Sniffen, C. J., O'Connor, J. D., Van Soest, P. J., Fox, D. G., \& Russell, J. B. (1992). A net carbohydrate and protein system for evaluating cattle diets: II. Carbohydrate and protein availability. Journal of Animal Science, 70(11), 3562-3577. doi: $10.2527 / 1992.70113562 x$

Souza, A. R. D. L., Medeiros, S. R., Morais, M. G., Oshiro, M. M., \& Torres, R. A. A., Jr. (2009). Dieta com alto teor de gordura e desempenho de tourinhos de grupos genéticos diferentes em confinamento. Pesquisa Agropecuaria Brasileira, 44(7), 746-753. doi: 10.1590/S0100-204X2009 000700015 
Souza, M. A., Detmann, E., Paulino, M. F., Sampaio, C. B., Lazzarini, Í., \& Valadares, S. C., Fo. (2010). Intake, digestibility and rumen dynamics of neutral detergent fibre in cattle fed low-quality tropical forage and supplemented with nitrogen and/or starch. Tropical Animal Health and Production, 42(6), 1299-1310. doi: 10.1007/s11250010-9566-6

Valadares, S. C., F., Silva, L. F. C., Gionbelli, M. P., Rotta, P. P., Marcondes, M. I., Chizzotti, M. L., \& Prados, L. F. (2016). Exigências nutricionais de zebuínos puros e cruzados - BR-CORTE (3nd ed.). Viçosa: UFV.

Valente, E. E. L., Filipini, V. T., Araújo, L. C., Stahlhofer, M., Melo, B. V. R., Bantle, E. L.,... Barbizan, M. (2019). Effect of heat load and dietary protein on oxygen pulse and energy cost for locomotion in heifers. Animal Production Science, 59(9), 1611. doi: 10.1071/AN18177

Valente, E. E. L., Paulino, M. F., Barros, L. V., Almeida, D. M., Martins, L. S., \& Cabral, C. H. A. (2014). Nutritional evaluation of young bulls on tropical pasture receiving supplements with different protein: carbohydrate ratios. Asian-Australasian Journal of Animal Sciences, 27(10), 14521460. doi: $10.5713 /$ ajas.2014.14085
Valente, T. N. P., Detmann, E., Queiroz, A. C., Valadares, S. C., Fo., Gomes, D. I., \& Figueiras, J. F. (2011). Evaluation of ruminal degradation profiles of forages using bags made from different textiles. Revista Brasileira de Zootecnia, 40(11), 25652573. doi: 10.1590/S1516-35982011001 100039

Valente, E. E. L., Paulino, M. F., Detmann, E., Valadares, S. D. C. Fo., \& Lopes, S. A. (2013). Performance of young bulls supplemented with different relation of protein and carbohydrate from suckling phase until slaughter in tropical pasture. Journal of Animal and Plant Sciences, 18, 2711-2722.

Williams, C. H., David, D. J., \& lismaa, O. (1962). The determination of chromic oxide in faeces samples by atomic absorption spectrophotometry. The Journal of Agricultural Science, 59(3), 381-385. doi: $10.1017 / S 002185960001546 X$ 